\title{
Benzonase pre-digest successfully reduces DNA from dead bacteria and the host
}

\author{
Yacine Amar \\ Ilias Lagkouvardos \\ Rafaela L. Silva \\ Oluwaseun Ayodeji Ishola \\ Bärbel U. Foesel \\ Susanne Kublik \\ Anne Schöler \\ Sebastian Niedermeier \\ Rachela Bleuel \\ Alexander Zink \\ Klaus Neuhaus \\ Michael Schloter \\ Tilo Biedermann \\ Martin Köberle
}

\section{Video Byte}

Keywords: Microbiome, Benzonase, DNA extraction, next generation sequencing, NGS, skin microbiome, 16S rRNA, diversity, skin, live/dead, low biomass, methods, methodology, digest, host DNA

Posted Date: October 14th, 2021

DOl: https://doi.org/10.21203/rs.3.rs-967807/v1

License: (9) This work is licensed under a Creative Commons Attribution 4.0 International License. Read Full License 


\section{Abstract}

Next-generation sequencing (NGS) studies have led to dramatic improvements in our understanding of human microbiomes. However, this method is based on the presence of DNA and cannot distinguish between living and dead microbes on its own. Environments like our skin are hostile and have high microbe turnover, which leads to significant amounts of DNA from dead microbes, which can lead to inaccurate community estimations in NGS studies. To overcome this, researchers tested the feasibility of pre-treatment with Benzonase to digest unprotected DNA. They used both mock bacterial communities and skin microbiome samples with inactivated bacteria or bacteria-free DNA spiked-in. Benzonase (BDA) pre-treatment reduced the levels of DNA from dead bacteria in both mock and natural communities. It also reduced the amount of host DNA in samples with high human-to-microbial DNA ratios without obvious impact on the microbial profile. Samples with very few bacteria showed an a-diversity bias, but the Benzonase digest was unable to overcome this. Taken together these results suggest that a Benzonase pre-digest is a viable method to improve the assessment of living bacteria and to reduce extracellular host DNA. 